\title{
Simultaneous PMC and PMSE observations with a ground-based lidar and SuperDARN HF radar at Syowa Station, Antarctica
}

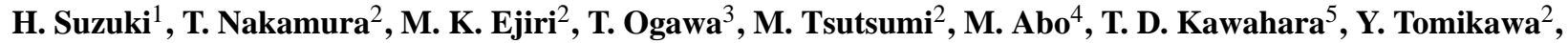 \\ A. S. Yukimatu ${ }^{2}$, and N. Sato ${ }^{2}$ \\ ${ }^{1}$ Rikkyo University, Toshimaku, Tokyo, Japan \\ ${ }^{2}$ National Institute of Polar Research, Tachikawa, Tokyo, Japan \\ ${ }^{3}$ National Institute of Information and Communications Technology, Koganei, Tokyo, Japan \\ ${ }^{4}$ Tokyo Metropolitan University, Hino, Tokyo, Japan \\ ${ }^{5}$ Shinshu University, Nagano, Japan \\ Correspondence to: H. Suzuki (hsuzuki@ rikkyo.ac.jp)
}

Received: 31 December 2012 - Revised: 17 July 2013 - Accepted: 27 August 2013 - Published: 24 October 2013

\begin{abstract}
A Rayleigh-Raman lidar system was installed in January 2011 at Syowa Station, Antarctica $\left(69.0^{\circ} \mathrm{S}, 39.6^{\circ} \mathrm{E}\right)$. Polar mesospheric clouds (PMCs) were detected by lidar at around 22:30 UTC (LT $-3 \mathrm{~h}$ ) on 4 February 2011, which was the first day of observation. This was the first detection of PMCs over Syowa Station by lidar. On the same day, a Super Dual Auroral Radar Network (SuperDARN) HF radar with oblique-incidence beams detected polar mesospheric summer echoes (PMSE) between 21:30 and 23:00 UTC. This event is regarded as the last PMC activity around Syowa Station during the austral summer season (2010-2011), since no other PMC signals were detected by lidar in February 2011. This is consistent with results of PMC and mesopause temperature observations by satellite-born instruments of AIM (Aeronomy of Ice in the Mesosphere)/CIPS (Cloud Imaging and Particle Size) and AURA/MLS (Microwave Limb Sounder) and horizontal wind measurements taken by a separate MF radar. Doppler velocity of PMSE observed by the HF radar showed motion toward Syowa Station (westward). This westward motion is consistent with the wind velocities obtained by the MF radar. However, the PMSE region showed horizontal motion from a north-to-south direction during the PMC event. This event indicates that the apparent horizontal motion of the PMSE region can deviate from neutral wind directions and observed Doppler velocities.
\end{abstract}

Keywords. Atmospheric composition and structure (middle atmosphere - composition and chemistry) - Ionosphere (Polar ionosphere) - Meteorology and atmospheric dynamics (middle atmosphere dynamics)

\section{Introduction}

Polar mesospheric clouds (PMCs), also known as noctilucent clouds (NLCs), are the highest altitude clouds in the Earth's atmosphere, and are produced at very low temperatures below the frost point $(<140 \mathrm{~K})$ in the mesopause region. The former term (PMCs) tends to be used for clouds that are observed from space, while the latter term (NLCs) represents visible phenomena from the ground. These clouds can only be observed during the summer season, when the polar mesopause region is coldest due to an adiabatic cooling caused by an upwelling motion induced by the global meridional circulation, which is driven by gravity wave acceleration (Lindzen, 1981). Since occurrences of these clouds are highly dependent on background conditions (i.e., temperature and mixing ratio of water vapor), PMCs are thought to be a possible indicator of Earth's environmental change. Thus, numerous ground-based observations have been conducted via human (visible) observations (e.g., Romejko et al., 2003; Kirkwood et al., 2008), a northern hemispheric network of automated cameras (Dalin et al., 2008, 2011; Dubietis et al., 2011), lidars in both the Northern Hemisphere (Hansen et al., 1989; Gardner et al., 2001; Wickwar et al., 2002; Fiedler et al., 2003; Collins et al., 2003; Thayer et al., 2003; Höffner et al., 2003) and the Southern Hemisphere (Gardner et al., 2001; Chu et al., 2003, 2004, 2006, 2011), and a combination of lidar and an imaging technique (Taylor et al., 2009), all of which have been used to analyze the occurrence and brightness of PMCs and NLCs. Space-born 


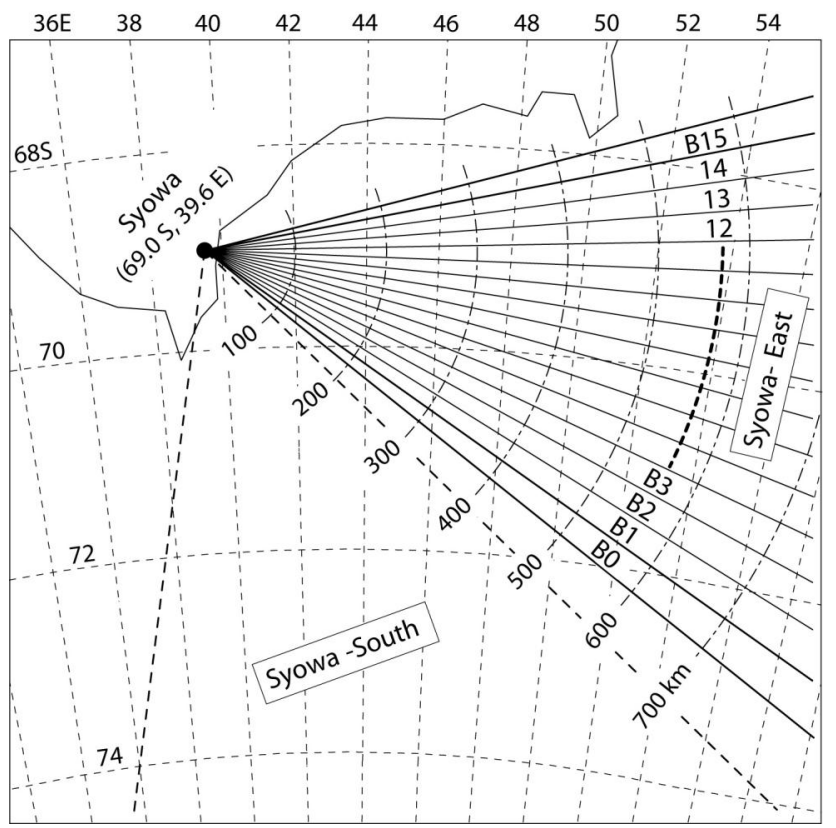

Fig. 1. Field of view for the Syowa-East HF radar with a 16-beam coverage (beams numbered as B0, B1, B2, .., B15). Ground ranges from Syowa Station and the Syowa-South HF radar field of view are also indicated with curved dot-dashed lines and black dashed lines, respectively.

observations via satellites have also made significant advances in the study of PMCs. For example, global satellite observations have revealed significant year-to-year variability (Hervig and Siskind, 2006), hemispheric asymmetry (e.g., Karlsson et al., 2011), and long-term trends of PMC activity (DeLand et al., 2006). On the other hand, altitude variation, small-scale structure, and local time dependence of PMC activity, all of which are generally difficult to analyze using satellite observations, have been studied mainly with lidar data (references as described above). In addition, a significant effect of short-period (several hours) gravity waves on PMC activity has been clearly detected by lidar at McMurdo Station (77.8 S), Antarctica (Chu et al., 2011).

Polar mesospheric summer echoes (PMSEs), which are strongly associated with PMCs occurrence, are extensively studied by various ground-based radars such as UHF radars (e.g., Nicolls et al., 2009), VHF radars (e.g., Palmer et al., 1996; Hoffmann et al., 1999; Smirnova et al., 2011), MF radars (e.g., Röttger, 1994; Bremer et al., 1996; Liu et al., 2002), and HF radars (Ogawa et al., 2002; Collins et al., 2003; Ramos et al., 2009). A common volume (CV) observation of PMCs and PMSEs was achieved by, for example, von Zahn and Bremer (1999) at sites in the Northern Hemisphere. In the Southern Hemisphere, the first CV observation was reported by Klekociuk et al. (2008) at Davis Station $\left(68.6^{\circ} \mathrm{S}\right.$, $\left.78.0^{\circ} \mathrm{E}\right)$, Antarctica. At Syowa Station $\left(69.0^{\circ} \mathrm{S}, 39.6^{\circ} \mathrm{E}\right)$, Antarctica, PMSE observations have been conducted using an oblique-incidence Super Dual Auroral Radar Network (SuperDARN) HF radar (e.g., Ogawa et al., 2002; Hosokawa et al., 2004). The first visual NLC at Syowa Station was photographed on 11 February 2009 (Takeda, 2010). At that time, however, there were no ground-based instruments capable of continuously monitoring PMC activity at Syowa Station. It is evident that the study of the relationship between local dynamics (gravity wave, turbulence, etc.) and behavior of PMC occurrence combined with PMSE is a very important subject in order to understand the physical processes associated with very low mesopause temperatures at high latitudes during the summer. A Rayleigh lidar was installed at Syowa Station in January 2011 to monitor atmospheric temperature from the upper troposphere to the mesosphere and clouds (polar stratospheric clouds and PMCs) at high altitudes. In this study, multiparametric observations using lidar (PMCs), HF radar (PMSEs), and MF radar (horizontal wind velocity) data are presented as the first successful simultaneous PMC and PMSE observation at Syowa Station.

\section{Instrumentation}

A Rayleigh-Raman lidar for profiling atmospheric temperature up to the mesosphere was developed for Antarctic observations. This lidar had been transported to Syowa Station by the 52nd Japanese Antarctic Research Expedition (JARE 52), and began operation on 4 February 2011. The main transmitter is a pulsed Nd:YAG laser $(355 \mathrm{~nm})$ with $300 \mathrm{~mJ}$ pulse energy and $20 \mathrm{~Hz}$ repetition frequency, which emits the beam into the vertical direction with a beam divergence of $\sim 0.5 \mathrm{mrad}$. The receiver telescope has an $82 \mathrm{~cm}$ diameter, and three photo multiplier tubes (PMTs) that are used to detect Rayleigh-scattered light from low and high altitudes at $355 \mathrm{~nm}$ and $\mathrm{N}_{2}$ Raman emission at $387 \mathrm{~nm}$. We analyzed signals of the most sensitive channel for an elastic scattering (Rayleigh high channel) in order to detect PMCs. The height resolution for this channel is $15 \mathrm{~m}$, and exposure time is $1 \mathrm{~min}$ (1200 shots). Further details and validations of this lidar system are described by Suzuki et al. (2012). In this study, a PMC signal was deduced by integrating photon counts over a vertical range of $990 \mathrm{~m}$ and a period of $20 \mathrm{~min}$ in order for the SNR of the PMC signals of the present event to be most significantly recognized.

Figure 1 shows field views of two HF radars, called Syowa-East and Syowa-South, at Syowa Station. These radars are part of SuperDARN, and were originally designed for the study of the ionospheric E- and F-region irregularities (Greenwald et al., 1995). Only data from the Syowa-East radar were available for the current study because the SyowaSouth radar was under maintenance. The Syowa HF radars first detected PMSE over Syowa Station in 1997 (Ogawa et al., 2002). As shown in Fig. 1, Syowa-East radar's field of view consists of 16 narrow beams (beam numbers B0, B1,B $2, \ldots, \mathrm{B} 15$; beam width $\sim 3.3^{\circ}$ ) over an azimuth sector of 

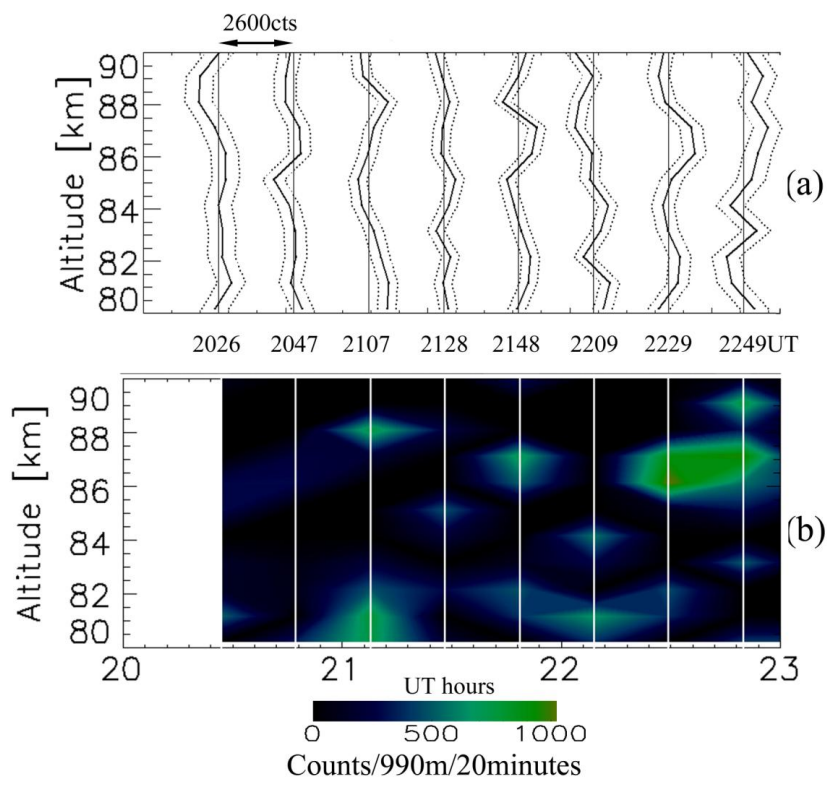

Fig. 2. (a) Count profiles of PMC signals observed by the Rayleigh lidar and (b) a color contour plot of the counts. Each line plot shows integrated counts over $20 \mathrm{~min}$ in time (24000 shots) and $990 \mathrm{~m}$ in altitude ( 66 bins). Solid and dotted lines in the upper panel represent zero counts and 1-sigma error levels, respectively. The vertical solid line shown in the lower panel corresponds to the averaged sampling time embedded between both panels.

$52^{\circ}$. The radar beam pattern in the vertical plane has maximum sensitivity at elevation angles of $15-35^{\circ}$ (depending on radar frequency) with an average half-power beam width of $\sim 30^{\circ}$. During the period of the current study, the beam was sequentially steered from beam B0 to beam B15 with an azimuth step of $3.3^{\circ}$, a scan repeat time of $\sim 50 \mathrm{~s}$, and a range resolution of $30 \mathrm{~km}$. The first range gate and the radar frequency were set to $60 \mathrm{~km}$ and approximately $10.2 \mathrm{MHz}$, respectively. The beam in the vertical plane at this frequency has maximum sensitivity at an elevation angle of $\sim 30^{\circ}$.

The MF radar is a monostatic pulse radar with a peak transmitting power of $50 \mathrm{~kW}$ and an operation frequency of $2.4 \mathrm{MHz}$. This instrument can be used to determine horizontal wind velocity (zonal, $u$; meridional, $v$ ) between 60 and $90 \mathrm{~km}$ in altitude with a sampling interval of $2 \mathrm{~km}$ when the D region of the ionosphere is not greatly disturbed by geomagnetic activity (e.g., Tsutsumi et al., 2001). In our study, MF radar data are used to estimate the mean background wind at altitudes of the observed PMC.

Satellite data are also employed in this study to compare our results of PMC occurrence and temperature trends of the mesopause over Syowa Station during the austral summer season between the summer solstice of 2010 and late February of 2011. A seasonal variation of the latitudinal dependence of PMC activity is analyzed using CIPS (Cloud Imaging and Particle Size) nadir (version 4.2) imager's summary data (level 3c); the imager is onboard the AIM (Aeronomy
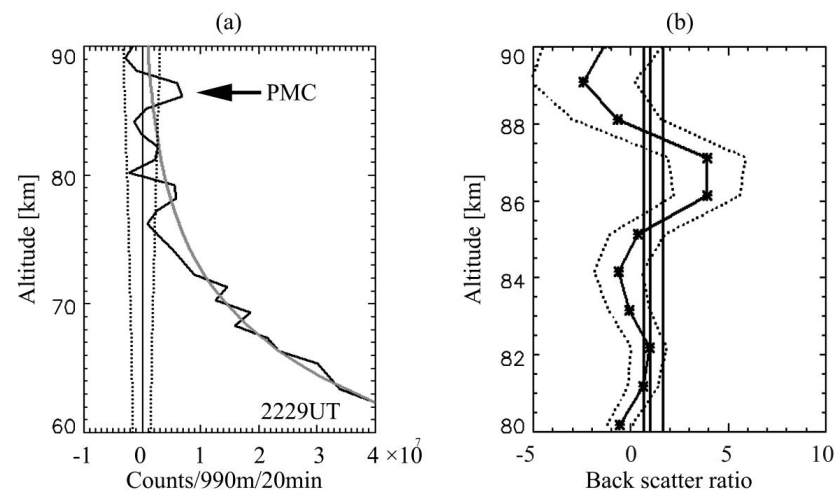

Fig. 3. (a) A photon count profile of data integrated between 22:19 and 22:39 UTC. The signal is corrected by multiplying $z$ (altitude) squared to raw count data. The vertical solid and dotted lines indicate zero counts and a 1-sigma error level, respectively. The gray solid curve shows estimated Rayleigh signals. (b) Backscatter ratio (BSR) between 80 and $90 \mathrm{~km}$ in altitude. The curved dotted lines show 1-sigma error of BSR. The two vertical lines show variability of an estimated Rayleigh signal relative to 1.0.

of Ice in the Mesosphere) satellite (Russell III et al., 2008; McClintock et al., 2009). Atmospheric temperature and humidity $\left(\mathrm{H}_{2} \mathrm{O}\right)$ at PMC altitudes near Syowa Station are analyzed using MLS (Microwave Limb Sounder) (version 3.3) data; this instrument is onboard the AURA satellite (Schwarz et al., 2008).

\section{Results}

Operation of the lidar system at Syowa Station began on 4 February 2011. Observations were conducted only during solar midnight on clear or partially cloudy nights in February 2011. Weather conditions, minimum solar elevation angles, and operation times in February 2011 are briefly summarized in Table 1. Among the seven days of observations, a PMC signal was detected only on the first day of observation (4 February 2011).

Figure 2 shows photon counts represented as (a) line plots and a (b) color contour plot, observed using the Rayleigh high channel of the Rayleigh lidar on 4 February 2011, and integrated over $20 \mathrm{~min}$ in time ( 24000 shots) and $990 \mathrm{~m}$ in altitude (66 bins). Note that the sky background, determined as an average photon count between 90 and $150 \mathrm{~km}$ in altitude, is not shown in Fig. 2. The dotted lines in the upper panel show an error standard deviation. The vertical solid lines in the lower panel correspond to centers of sampling times. Signals larger than the background level by more than one standard error level are seen in profiles at 21:48 UTC and 22:29 UTC around altitudes of $86-87 \mathrm{~km}$. In particular, the profile at 22:29 UTC shows clearer features, which is considered to be due to the presence of PMCs. Thus, PMC features at this time are discussed in the following analysis. The 
(a) Echo power

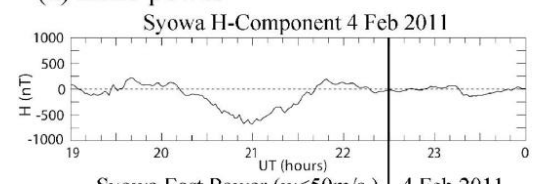

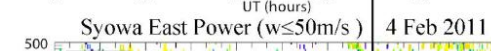

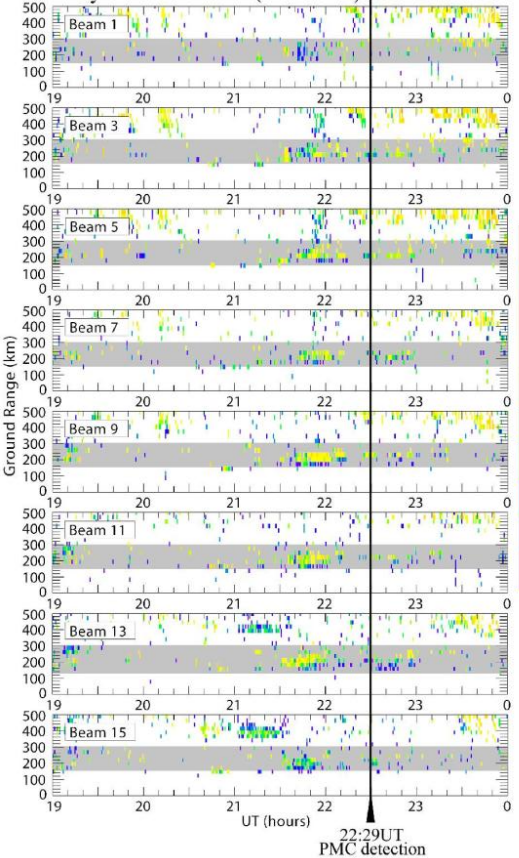

(b) Doppler velocity
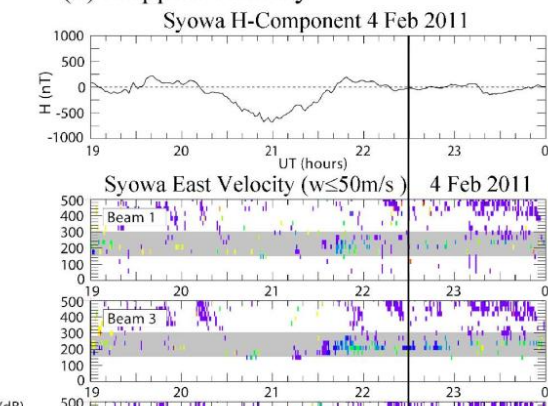

\section{(1) \\ :}

${ }^{32}$ है

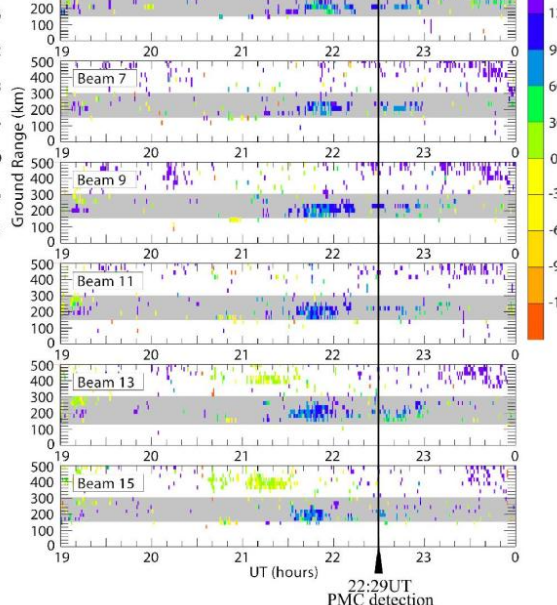

Fig. 4. Time and ground range variations of (a) echo power, (b) Doppler velocity, and (c) spectral width for beams 1, 3, 5, 7, 9, 11, 13, and 15 between 19:00 and 24:00 UTC. Data with a spectral width less than $50 \mathrm{~m} \mathrm{~s}^{-1}$ are plotted. Time variation of the geomagnetic $H$ component at Syowa Station is also shown in each figure (top panel). The most sensitive regions for PMSE detection (ground range 150-300 km) are displayed with gray bands.

Table 1. List of lidar observations and weather conditions in February 2011 at Syowa Station.

\begin{tabular}{ccccc}
\hline $\begin{array}{c}\text { Date } \\
(\text { Feb 2011 })\end{array}$ & $\begin{array}{c}\text { Time } \\
(\mathrm{UT})\end{array}$ & $\begin{array}{c}\text { Weather } \\
\text { condition }\end{array}$ & $\begin{array}{c}\text { PMC } \\
\text { detection }\end{array}$ & $\begin{array}{c}\text { Minimum solar elevation } \\
\text { angle }\left(^{\circ}\right)\end{array}$ \\
\hline 4 & $2018-2323$ & Clear & Yes & -4.9 \\
5 & $2049-2330$ & Clear & No & -5.2 \\
7 & $1936-2322$ & Clear & No & -5.9 \\
8 & $1912-2325$ & Partly cloudy & No & -6.2 \\
9 & $1936-2330$ & Partly cloudy & No & -6.5 \\
11 & $2004-2333$ & Clear & No & -7.2 \\
12 & $2017-2335$ & Clear & No & -7.5 \\
\hline
\end{tabular}

backscatter ratio (BSR) of PMCs is represented as

$\operatorname{BSR}=\frac{I_{\mathrm{t}}(z)}{I_{\mathrm{R}}(z)}$,

where $I_{\mathrm{t}}(z)$ is the total photon count including both PMC and atmospheric (Rayleigh) signals, and $I_{\mathrm{R}}(z)$ is the photon count purely due to scattering from atmospheric molecules. The atmospheric signal $I_{\mathrm{R}}(z)$ above $\sim 70 \mathrm{~km}$ is too weak to be estimated directly using a single profile as shown in Fig. 2. Therefore, we integrated all the profiles shown in Fig. 2 for the entire observation period to produce a nightly mean count profile, $\bar{I}_{\mathrm{t}}(z)$. This is then multiplied by $z$ (altitude) squared, $\bar{I}(z)=z^{2} \bar{I}_{\mathrm{t}}(z)$. Logarithmic signal intensities, $\log \bar{I}(z)$, are then fitted with a linear relationship between 60 and $80 \mathrm{~km}$,

$\bar{I}_{\mathrm{t}}(z)=-\frac{1}{H} z+\log \bar{I}_{0}$,

where $H$ is the density scale height, and $\bar{I}_{0}$ is the count at $z=0$ (surface). Using the least-squares method, $H$ and $\bar{I}_{0}$ are estimated as representative values. The same least-squares 
Syowa-East Echo Power (Width $\leq 50 \mathrm{~m} / \mathrm{s}$ ) 4 February 2011 (10.2 MHz)

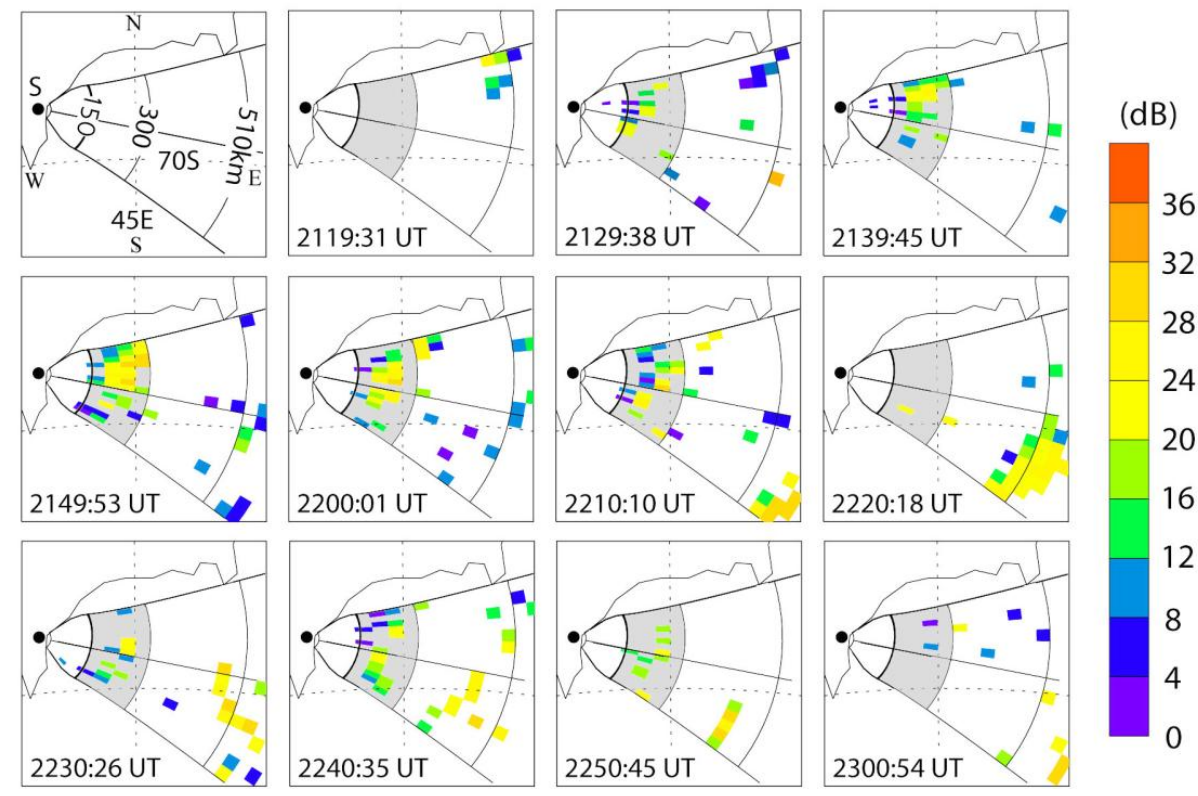

Fig. 5. Two-dimensional plots for time variation of echo power (with a spectral width smaller than 50 $\mathrm{ms}^{-1}$ ) between $21: 09: 25$ and 23:00:54 UTC. Location of Syowa Station, radar field of view, and ground ranges are indicated in the top left panel. The most sensitive regions for PMSE detection (ground range 150-300 km) are displayed with a gray band.

fitting technique is then applied to each signal profile averaged over $20 \mathrm{~min}$ in time and $990 \mathrm{~m}$ in altitude, with $H$ fixed to the value determined by the fitting to the nightly average, and the height for fitting is restricted to a range between 60 and $70 \mathrm{~km}$. The atmospheric signal, $I_{\mathrm{R}}(z)$, for each time is then estimated using the relationship $I_{\mathrm{R}}(z)=\bar{I}_{0}^{\prime} \exp (-z / H)$, where $\bar{I}_{0}^{\prime}$ is the estimated parameter corresponding to $\bar{I}_{0}$ in Eq. (2). Estimated $I_{\mathrm{R}}(z)$ and observed $I_{\mathrm{t}}(z)$ between $22: 19$ and 22:39 UTC are shown in Fig. 3a. The vertical solid line indicates zero counts, and the two dotted lines indicate a 1sigma error level when counts $=0$. Estimated atmospheric signals are plotted by a gray solid line. Figure $3 \mathrm{~b}$ shows BSR between 80 and $90 \mathrm{~km}$ derived using Eq. (1). Peak altitude $(z c)$ and BSR at 22:29 UTC are $86.6 \pm 0.5 \mathrm{~km}$ and $4 \pm 2$, respectively.

PMSE were detected using the Syowa-East HF radar (see Fig. 1) on the same day. Figure 4 shows time and ground range variations of (a) echo power, (b) Doppler velocity, and (c) spectral width on beams B1, B3, B5, B7, B9, B11, B13, and B15 between 19:00 and 24:00 UTC. Positive (negative) Doppler velocity (Fig. 4b) values indicate motion towards (away from) the radar site. The gray bands in each plot correspond to a ground range between 150 and $300 \mathrm{~km}$. This region is most sensitive for PMSE detection when using a field view of a HF radar (Ogawa et al., 2002). A time variation of the geomagnetic horizontal $(H)$ component at Syowa Station is also plotted in each figure. The $H$ component varied between 19:00 and 24:00 UTC, resulting in detection of strong radar echoes from E-region field-aligned irregularities (E-FAI) in addition to echoes from the upper mesosphere. In order to exclude possible E-FAI echoes that exist at a similar range to mesospheric echoes $(150-300 \mathrm{~km})$ and to extract echoes from the upper mesosphere, only data with a spectral width smaller than $50 \mathrm{~m} \mathrm{~s}^{-1}$ were selected and plotted in Fig. 4, since E-FAI echoes have a much larger spectral width (typically $>100 \mathrm{~m} \mathrm{~s}^{-1}$ ). It is known that PMSE appearing during quiet geomagnetic conditions have spectral widths smaller than $50 \mathrm{~m} \mathrm{~s}^{-1}$ (Ogawa et al., 2002, 2003a, b).

In Fig. 4, PMSE with maximum echo powers of about $30 \mathrm{~dB}$ are clearly observed at ground ranges around $200 \mathrm{~km}$ between 21:30 and 23:00 UTC for all beams. Echoes at other times or at ranges beyond $300 \mathrm{~km}$ are possibly due to E- and/or F-FAI echoes with spectral widths smaller than $50 \mathrm{~m} \mathrm{~s}^{-1}$. The appearance of PMSE at around $200 \mathrm{~km}$ for all beams is consistent with the results of Ogawa et al. (2002) and Hosokawa et al. (2005). All Doppler velocities of PMSE in Fig. $4 \mathrm{~b}$ are positive, and therefore westward (see Fig. 1).

Figure 5 displays time variation (every $\sim 10 \mathrm{~min}$ ) of the two-dimensional echo power map between 21:19:31 and 23:00:54 UTC for echoes with spectral widths smaller than $50 \mathrm{~m} \mathrm{~s}^{-1}$. The radar field of view and ground ranges are shown in the upper-left panel. The most sensitive regions for PMSE detection (ground range 150-300 km) are indicated with a gray band, as in Fig. 4. Echoes at ranges far beyond $300 \mathrm{~km}$ are mainly due to E- and/or F-FAI with narrow spectral widths. 
(a) Mean Cloud Albedo [1/str]

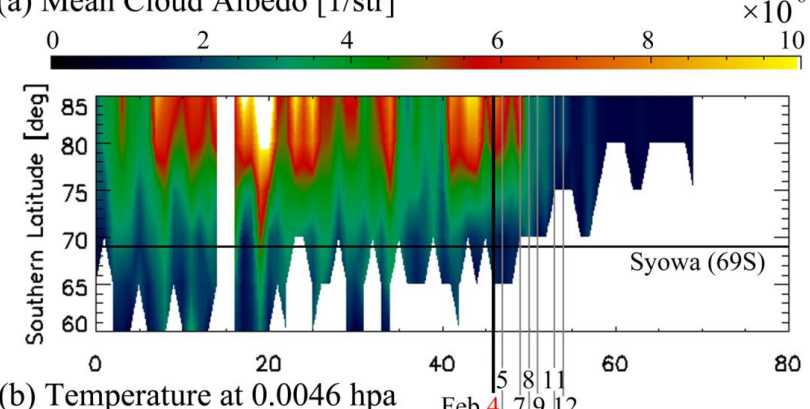

(b) Temperature at $0.0046 \mathrm{hpa}$ Feb.4 $7|9| 12$

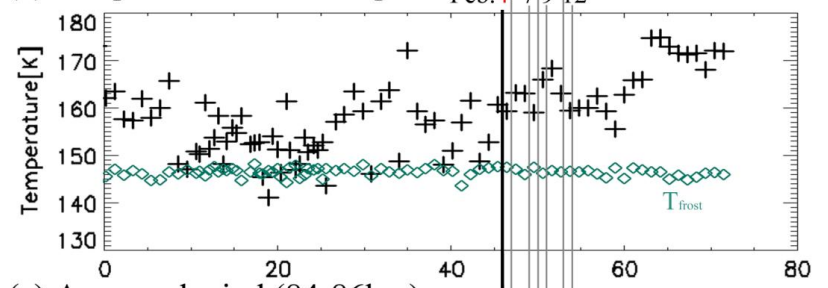

(c) Averaged wind (84-86km)

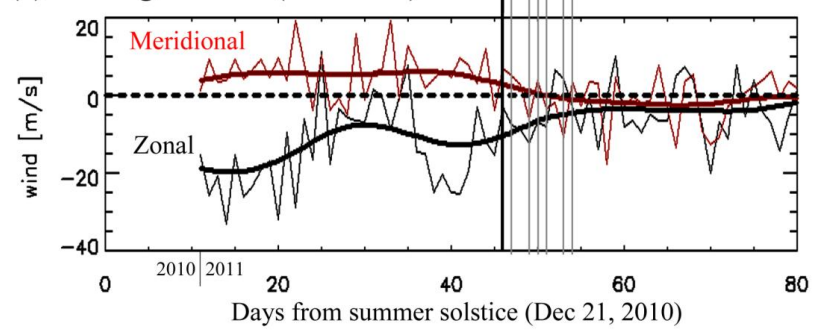

Fig. 6. (a) Color contour of mean cloud albedo measured by AIM/CIPS. This shows daily averaged cloud albedos within a longitudinal range of $39.6^{\circ} \pm 45.0^{\circ}$ and within a latitudinal range of 60 to $85^{\circ} \mathrm{S}$ in $5.0^{\circ}$ increments with $5.0^{\circ}$ variations (i.e., $60^{\circ} \pm 5^{\circ} \mathrm{S}$, $\left.65^{\circ} \pm 5^{\circ}, \ldots, 85^{\circ} \pm 5^{\circ}\right)$. (b) Mesospheric temperature plot for the mesopause region $(0.0046 \mathrm{hPa}$ in pressure, $\sim 85 \mathrm{~km}$ in altitude) measured by AURA/MLS satellite instruments. Each plus symbol corresponds to one sounding taken over a tangential point within $250 \mathrm{~km}$ of Syowa Station for each swath. If more than three data points satisfy this $250 \mathrm{~km}$ distance from Syowa Station, data of the closest point is plotted. The green diamonds the show frost point, $T_{\text {frost }}$. (c) Daily mean horizontal winds averaged between 84 and $86 \mathrm{~km}$ observed with the MF radar at Syowa Station. Black and red solid lines show zonal and meridional winds, respectively. Bold lines show smoothed winds using the Hanning window with a full width of 28 days. Vertical background lines for each panel show the nights with lidar observation at Syowa Station.

The possible relationship between PMCs and PMSE observed during this event is discussed in the following section.

\section{Discussion}

Statistical results of lidar observations over three summer seasons, between the end of 2002 and early 2005, at Rothera Station $\left(67.5^{\circ} \mathrm{S}, 68.0^{\circ} \mathrm{W}\right)$ suggest the mean altitude of PMCs is $84.12 \pm 0.21 \mathrm{~km}$ (Chu et al., 2006). Simultaneous observations of PMCs and PMSE during one austral summer from 2005 to 2006 were conducted at Davis Station $\left(68.6^{\circ} \mathrm{S}\right.$, $78.0^{\circ} \mathrm{E}$ ), and the results suggest a mean PMC and PMSE altitude of $83.97 \pm 0.10 \mathrm{~km}$ (standard deviation, $\sigma=1.0 \mathrm{~km}$ ) and $85.31 \pm 0.14 \mathrm{~km}(\sigma=1.3 \mathrm{~km})$, respectively (Klekociuk et al., 2008). Recently, the mean PMC altitude at Davis Station was deduced by using a longer period in the data set (2001 to $2009)$, and shows a very similar value of $83.97 \pm 0.07 \mathrm{~km}$ $(\sigma=2.71 \mathrm{~km})$ (Kaifler et al., 2013). Results from another Antarctic station (Wasa, $73.1^{\circ} \mathrm{S}, 13.4^{\circ} \mathrm{W}$ ) using VHF radar also show that the peak occurrence rate of PMSE appears at around $85 \mathrm{~km}$ (Kirkwood et al., 2007). The altitude of the PMC, $z c=86.6 \mathrm{~km}$, observed at Syowa Station, as shown in Fig. 3, is slightly higher than the above-mentioned previous lidar observations conducted at southern high latitudes similar to Syowa Station. The peak BSR of the PMC for the present case was $4 \pm 2$. Chu et al. (2006) also reported a mean peak BSR of a PMC observed over Rothera Station; BSR = $17.8 \pm 0.64(\sigma=7.3)$ at an operating wavelength $(374 \mathrm{~nm})$ of their iron Boltzmann lidar. To compare this value with our result, the dependence on wavelength for the backscattering coefficients by both atmospheric molecules $\left(\beta_{\mathrm{R}}\right)$ and the PMC $(\beta \mathrm{pmc})$ should be taken into account. This correction is expressed as follows:

$\mathrm{BSR}_{355}=\left(\frac{\beta_{374, R}}{\beta_{355, R}}\right)\left(\frac{\beta_{355, \mathrm{PMC}}}{\beta_{374, \mathrm{PMC}}}\right)\left(\mathrm{BSR}_{374}-1\right)+1$.

The ratio of the backscattering coefficients of the PMC at two wavelengths $\left(\beta_{355, \mathrm{pmc}} / \beta_{374, \mathrm{pmc}}\right)$ is referred to as the "color ratio" and is about 1.1 for this wavelength combination (Baumgarten et al., 2007; Höffner et al., 2003). The ratio of the backscattering coefficients of the Rayleigh scattering can be estimated as $\left(\beta_{374, \mathrm{R}} / \beta_{355, \mathrm{R}}\right)=(355 / 374)^{4} \sim 0.8$ by its $\lambda^{-4}$ dependence. Thus, the correction to convert the BSR at $374 \mathrm{~nm}$ to the BSR at $355 \mathrm{~nm}$ is expressed as $\mathrm{BSR}_{355}=$ $0.8 \times 1.1 \times\left(\mathrm{BSR}_{374}-1\right)+1$. If $\mathrm{BSR}_{374}$ is set to 17.8 , then $\mathrm{BSR}_{355}$ is calculated as 15.8. Therefore, the observed BSR $(\mathrm{BSR}=4)$ by our lidar was very weak relative to the results by Chu et al. (2006), even if this effect is taken into account.

As shown in Table 1, PMCs were only detected on 4 February 2011 over Syowa Station. Figure 6a shows mean cloud albedo and (b) mesospheric temperatures of the mesopause regions $(0.0046 \mathrm{hPa}$ in pressure, $\sim 85 \mathrm{~km}$ in altitude) observed by AIM/CIPS and AURA/MLS satellite instruments. The green diamonds in Fig. $6 \mathrm{~b}$ indicate the frost point, $T_{\text {frost }}$, estimated by using Aura humidity values $\left(\mathrm{H}_{2} \mathrm{O}\right)$ and a formula of saturation pressure of water vapor over ice (Stevens et al., 2001) at an altitude of $0.0046 \mathrm{hPa}(\sim 85 \mathrm{~km})$. The PMC albedo shown in Fig. 6a is the daily averaged value within a longitudinal range of $39.6^{\circ} \pm 45.0^{\circ}$ and within a latitudinal range of 60 to $85^{\circ} \mathrm{S}$ in $5.0^{\circ}$ increments with $5.0^{\circ}$ variations (i.e., $60^{\circ} \mathrm{S} \pm 5^{\circ}, 65^{\circ} \pm 5^{\circ}, \ldots, 85^{\circ} \pm 5^{\circ}$ ). Each symbol (plus) in Fig. 6b corresponds to a single sounding taken over a tangential point within $250 \mathrm{~km}$ of Syowa Station $\left(69.0 \pm 2.3^{\circ} \mathrm{S}, 39.5 \pm 6.4^{\circ} \mathrm{E}\right)$ for each swath. Vertical lines indicate nights with lidar observation at Syowa Station, 
of which only on 4 February 2011 (thick line) was a PMC detected. Figure 6a shows a reduction of the PMC region at higher latitudes in February. PMC activity near the latitude of Syowa Station continued until about 45 to 50 days after the summer solstice, and did not occur again after this period. Temperatures around PMC altitudes $(\sim 85 \mathrm{~km})$, as shown in Fig. 6b, gradually increased from day 40 to 70 . The range of temperature variation was $140-170 \mathrm{~K}$ and $150-180 \mathrm{~K}$ before and after 4 February 2011, respectively. In other words, the temperature sometimes reached below frost point $(\sim 145 \mathrm{~K})$ on the day before 4 February 2011. However, the temperature after the day is greater than $155 \mathrm{~K}$ ( $\left.>T_{\text {frost }}\right)$. Daily mean horizontal winds averaging around $85.0 \pm 3.0 \mathrm{~km}$ in altitude were observed with the MF radar at Syowa Station, and are shown in Fig. 6c. The meridional wind (red solid line) changed from northward to southward five days after the PMC event, implying background temperature above Syowa Station shifted from that of a cold summer to a warm winter during this period. Both trends shown by satellite temperature data and MF radar wind data are consistent with the PMC observation.

The atmospheric temperature during the lidar observation period (4-11 February 2011) did not show any drastic variation, and did not descend below $T_{\text {frost }}$. However, PMCs were only detected on the night of 4 February 2011. This fact implies that small-scale disturbances in temperature fields caused by atmospheric gravity waves or other local phenomena play an important role on PMC activity, since MLS temperature data are not sampled completely in CV. Another possibility is that a decrease in equatorward wind reduces the transportation of PMCs from higher latitude regions where PMCs are still actively formed. The PMC detected over Syowa Station on 4 February 2011 is thought to be the last observation at the end season of PMC activity around Syowa Station. A relationship between background winds using MF radar data, temperature using AURA/MLS data, and PMSE occurrence using VHF radar data at Davis Station between 2004 and 2005 (Morris et al., 2007) was very similar to the present case.

The PMSE shown in Figs. 4 and 5 were detected to the east of Syowa Station, since the sampling region of the HF radar, which has wide azimuth coverage $\left(52^{\circ}\right)$, was directed towards geographical east as shown in Fig. 1. On the other hand, lidar detected backscatter from the zenith of Syowa Station. Thus, both instruments did not observe a CV, contrary to the case of Klekociuk et al. (2008), who used both Rayleigh lidar and VHF radar. However, our obliqueincidence HF radar could detect a two-dimensional distribution and motion of PMSE regions in wide areas (Ogawa et al., 2002).

Figure 7 shows color contour plots of $10 \mathrm{~min}$ averaged zonal $(u$, upper panel) and meridional $(v$, lower panel) winds observed by the Syowa Station MF radar. The white vertical and horizontal lines show the time (22:29 UTC) and peak altitude $(86.6 \mathrm{~km})$ of PMC occurrence, respectively, taken from Fig. 3. The zonal winds' directions around the PMC altitude
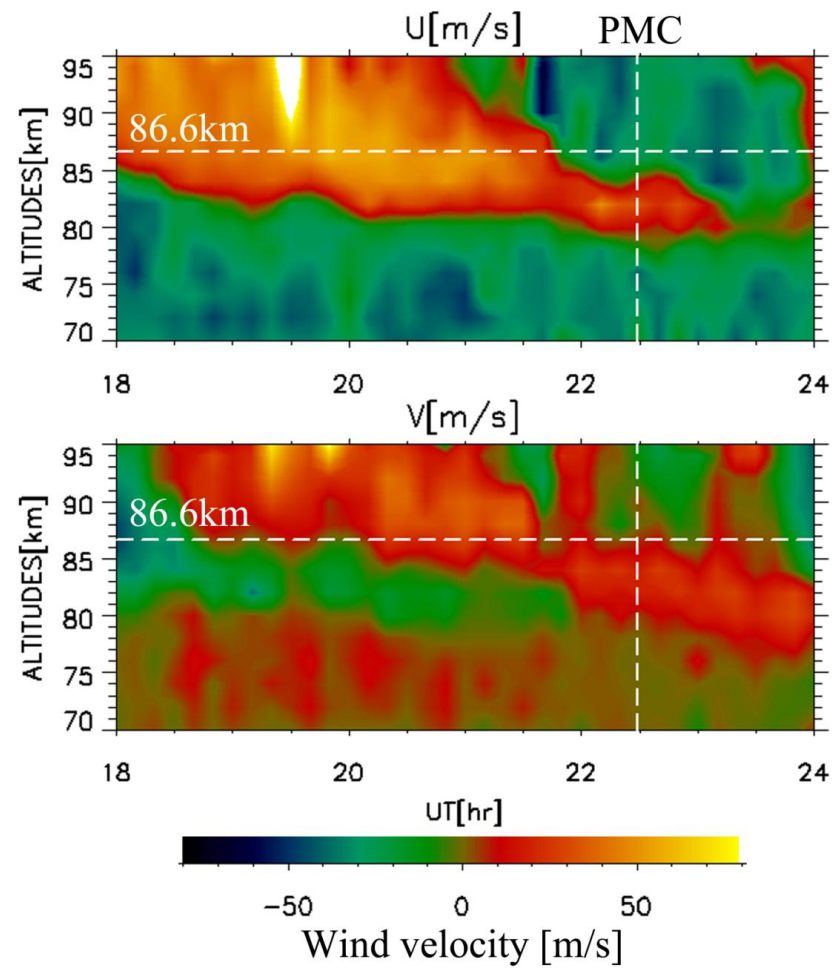

Fig. 7. Color contour plots of $10 \mathrm{~min}$ averaged zonal ( $u$, upper panel) and meridional ( $v$, lower panel) wind observed by the MF radar. White vertical and horizontal lines indicate the time (22:29 UTC) and peak altitude of the PMC $(86.6 \mathrm{~km})$ observed by lidar as shown in Fig. 3.

between 21:30 and 23:00 UTC (see Fig. 4) were mostly westward with an amplitude of $10-40 \mathrm{~m} \mathrm{~s}^{-1}$. This westward wind direction is consistent with positive (toward Syowa Station) Doppler velocities of PMSE (Fig. 4b). However, Doppler velocities near ground ranges of $\sim 200 \mathrm{~km}$ between 21:30 and 23:00 UTC were very large, and sometimes exceeded $+100 \mathrm{~m} \mathrm{~s}^{-1}$. In addition, these velocities are a projection onto the radar coverage, and therefore can be larger when Doppler velocity is converted to horizontal velocity in most cases. It is reported that Doppler velocity of PMSE agrees well with neutral wind observed by MF radar under quiet geomagnetic conditions (Ogawa et al., 2004). In general, motion of plasma irregularities causing PMSE is controlled by both neutral wind and the background ionospheric electric field. As shown in Fig. 4, when the PMSE were observed, a medium-scale geomagnetic storm was in progress, suggesting that the irregularity motion was more affected by the electric field. Thus, the quantitative inconsistency between HF radar Doppler velocity and MF radar neutral wind measurements can be explained by an electric field caused by a geomagnetic storm.

In addition, the PMSE region showed horizontal motion from north to south between 21:39 and 22:20 UTC. Figure 8 shows strong echo regions with echo power greater 


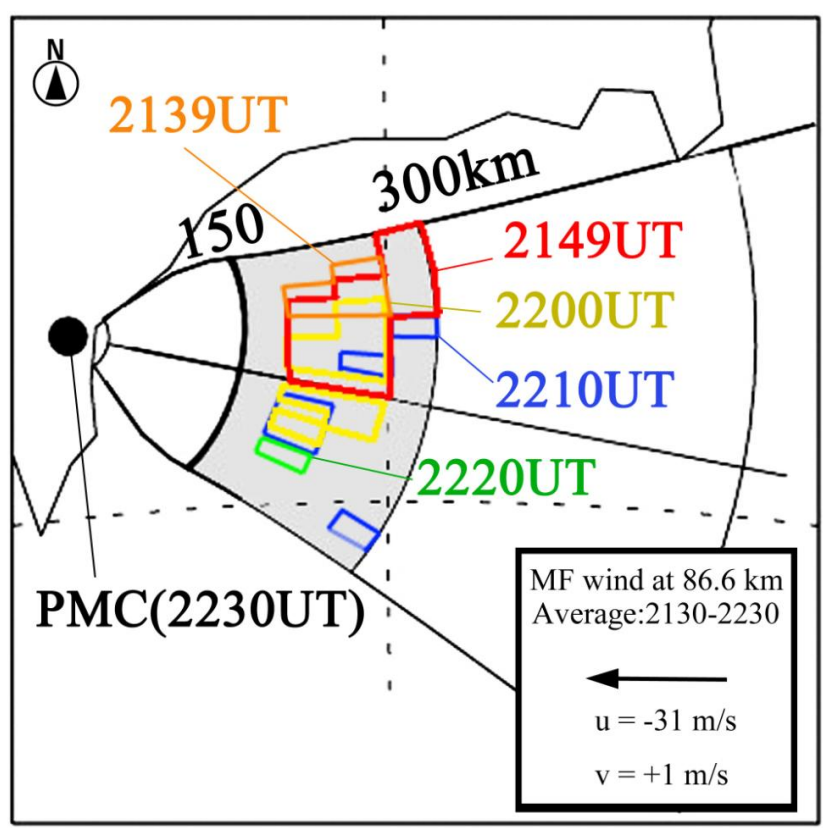

Fig. 8. Spatiotemporal variation of the strong echo region $(>20 \mathrm{~dB})$ for the ground range between 150 and $300 \mathrm{~km}$. The wind vector at the PMC altitude $(86.6 \mathrm{~km})$ scaled by the distance of wind advection for one hour is also shown.

than $20 \mathrm{~dB}$. This clearly indicates a southward motion of the PMSE region. The horizontal neutral wind velocity at the PMC altitude $(z c=86.6 \mathrm{~km})$ obtained by MF radar is also shown in the bottom-right corner of Fig. 8. The horizontal wind greatly differed from the apparent motion of the echo region. According to a statistical study by Klekociuk et al. (2008), the mean altitude of PMSE is $85.31 \pm 0.14 \mathrm{~km}$ $(\sigma=1.3 \mathrm{~km})$ at Davis Station. However, the neutral winds measured by the MF radar (Fig. 7) show no large wind shear near the PMC altitude within such a range. Thus, the direction of the apparent motion of the PMSE region was quite different from that of the neutral wind during this event. PMSE power is also perturbed by atmospheric waves (Huaman and Kelley, 2002) as well as PMCs (Chandran et al., 2010; Chu et al., 2011; Kaifler et al., 2013). Recently, Dalin et al. (2012) showed that the variability of the PMSE layer is also controlled by the ice number density and its height gradient, induced by wave-induced perturbations and turbulent energy dissipation. Thus, the horizontal displacement of the strong echo region is also likely due to a propagation of atmospheric gravity waves. A detailed study of ionospheric disturbance and atmospheric wave effects on PMSE Doppler velocity and power will be an objective in future work.

The origin of the observed PMC and PMSE is thought to be strongly related to each another. Electron density irregularities due to charged ice particles induce PMSE, and grown water-ice sediment from PMSE altitudes is detected as PMC (Reid, 1990; Lübken et al., 1998; von Zhan and Bre- mer, 1999; Rapp and Lübken, 2004). The present case also supports a strong relationship between PMCs and PMSE, although more data and $\mathrm{CV}$ observations are needed to study the detailed physical processes.

A powerful VHF MST radar, with $500 \mathrm{~kW}$ output power and $18000 \mathrm{~m}^{2}$ antenna aperture, called PANSY (Program of the Antarctic Syowa MST/IS) radar, was installed at Syowa Station in 2011. The research observation by PANSY started in late April of 2012 with 25\% full antenna system operation. PANSY can be a powerful tool for PMSE study in addition to other radars. This radar system can be operated as an imaging radar that can resolve the 3-D structure of PMSE over Syowa Station. Detailed multiparameter observations of PMC and PMSE using lidar, SuperDARN HF radar, MF radar, and PANSY are expected to be objectives in future work.

\section{Conclusion}

Simultaneous observations of PMCs and PMSE using a Rayleigh-Raman lidar system and a SuperDARN HF radar were conducted on 4 February 2011, at Syowa Station, Antarctica. This is the first detection of PMCs via lidar at Syowa Station. Estimated BSR and peak altitude of a PMC at 22:29 UTC were $4 \pm 2$ and $86.6 \pm 0.5 \mathrm{~km}$, respectively. Lidar observations after this date did not detect any PMC signals. AIM/CIPS satellite data also showed weaker activities of PMC around the latitude of Syowa Station after this event. In addition, AURA/MLS satellite data showed a phase of increased atmospheric temperature at PMC altitudes around this date. The temperature sometimes reached below the frost point $\left(T_{\text {frost }}\right)$ on the days before 4 February 2011 . However, the temperature after the day is greater than that level. Thus, the PMC detected on 4 February 2011 is regarded as the last observation near the end of the PMC season for latitudes similar to Syowa Station during the austral summer from 2010 to 2011.

Zonal winds near the PMC altitude during this event were mostly westward with an amplitude of $10-40 \mathrm{~m} \mathrm{~s}^{-1}$. The westward wind direction is consistent with the positive (toward Syowa Station) Doppler velocities of PMSE using the HF radar. However, the PMSE echo region showed southward horizontal motion during this period. This suggests that horizontal variation of the PMSE region is not simply controlled by neutral background wind but instead by other effects, such as an electric field or vertical displacement due to atmospheric waves. Detailed multiparametric and CV observations of PMC and PMSE using lidar and PANSY radar are expected to solve these problems in the future.

Acknowledgements. This work was supported by JSPS Grant-inAid for Scientific Research (B) (grant number 24340121), Grantin-Aid for Young Scientists (B) (grant number 25800276) and KP-2 project of National Institute of Polar Research. The Syowa 
Rayleigh-Raman lidar, the HF radar, and the MF radar are operated by Japanese Antarctic Research Expedition (JARE). The authors acknowledge the support from the Aura and AIM projects as well as the MLS and CIPS teams for making the temperature and cloud imaging data available.

Topical Editor C. Jacobi thanks three anonymous referees for their help in evaluating this paper.

\section{References}

Baumgarten, G., von Cossart, G., and Fiedler, J.: The size of noctilucent cloud particles above ALOMAR (69 N, 16E): Optical modeling and method description, Adv. Space Res., 40, 772-784, doi:10.1016/j.asr.2007.01.018, 2007.

Bremer, J., Hoffmann, P., Manson, A. H., Meek, C. E., Rüster, R., and Singer, W.: PMSE observations at three different frequencies in northern Europe during summer 1994, Ann. Geophys., 14, 1317-1327, doi:10.1007/s00585-996-1317-7, 1996.

Chandran, A., Rusch, D. W., Merkel, A. W., Palo, S. E., Thomas, G. E., Taylor, M. J., Bailey, S. M., and Russell III, J. M.: Polar mesospheric cloud structures observed from the cloud imaging and particle size experiment on the Aeronomy of Ice in the Mesosphere spacecraft: Atmospheric gravity waves as drivers for longitudinal variability in polar mesospheric cloud occurrence, J. Geophys. Res., 115, D13102, doi:10.1029/2009JD013185, 2010.

Chu, X., Gardner, C. S., and Roble, R. G.: Lidar studies of interannual seasonal and diurnal variations of polar mesospheric clouds at the South Pole, J. Geophys. Res., 108, 8447, doi:10.1029/2002JD002524, 2003.

Chu, X., Nott, G. J., Espy, P. J., Gardner, C. S., Diettrich, J. C., Clilverd, M. A., and Jarvis, M. J.: Lidar observations of polar mesospheric clouds at Rothera, Antarctica (67.5 S, 68.0 W), Geophys. Res. Lett., 31, L02114, doi:10.1029/2003GL018638, 2004.

Chu, X., Espy, P. J., Nott, G. J., Diettrich, J. C., and Gardner, C. S.: Polar mesospheric clouds observed by an iron Boltzmann lidar at Rothera (67.5 S, 68.0 W), Antarctica from 2002 to 2005: Properties and implications, J. Geophys. Res., 111, D20213, doi:10.1029/2006JD007086, 2006.

Chu, X., Huang, W., Fong, W., Yu, Z., Wang, Z., Smith, J. A., and Gardner, C. S.: First lidar observations of polar mesospheric clouds and $\mathrm{Fe}$ temperatures at McMurdo $\left(77.8^{\circ} \mathrm{S}, 166.7^{\circ} \mathrm{E}\right)$, Antarctica, Geophys. Res. Lett., 38, L16810, doi:10.1029/2011GL048373, 2011.

Collins, R. L., Kelley, M. C., Nicolls, M. J., Ramos, C., Hou, T., Stern, T. E., Mizutani, K., and Itabe, T.: Simultaneous lidar observations of a noctilucent cloud and an internal wave in the polar mesosphere, J. Geophys. Res., 108, 8435, doi:10.1029/2002JD002427, 2003.

Dalin, P., Pertsev, N., Zadorozhny, A., Connors, M., Schofield, I., Shelton, I., Zalcik, M.,McEwan, T., McEachran, I., Frandsen, S., Hansen, O., Andersen, H., Sukhodoev, V., Perminov, V., and Romejko, V.: Ground-based observations of noctilucent clouds with a Northern Hemisphere network of automatic digital cameras, J. Atmos. Solar-Terr. Phys., 70, 1460-1472, doi:10.1016/j.jastp.2008.04.018, 2008.

Dalin, P., Pertsev, N., Dubietis, A., Zalcik, M., Zadorozhny, A., Connors, M., Schofield, I., McEwan, T., McEachran, I., Frandsen, S., Hansen, O., Andersen, H., Sukhodoev, V.,Perminov, V., Balčiunas, R., and Romejko, V.: A comparison between ground-based observations of noctilucent clouds and Aura satellite data, J. Atmos. Sol-Terr. Phys., 73, 2097-2109, doi:10.1016/j.jastp.2011.01.020, 2011.

Dalin, P., Kirkwood, S., Hervig, M., Mihalikova, M., Mikhaylova, D., Wolf, I., and Osepian, A.: Wave influence on polar mesosphere summer echoes above Wasa: experimental and model studies, Ann. Geophys., 30, 1143-1157, doi:10.5194/angeo-301143-2012, 2012.

DeLand, M. T., Shettle, E. P., Thomas, G. E., and Olivero, J. J.: A quarter-century of satellite PMC observations, J. Atmos. Sol. Terr. Phys., 68, 9-29, 2006.

Dubietis, A., Dalin, P., Balciunas, R., Cernis, K., Pertsev, N., Sukhodoev, V., Perminov, V., Zalcik, M., Zadorozhny, A., Connors, M., Schofield, I., McEwan, T., McEachran, I., Frandsen, S., Hansen, O., Andersen, H., Grönne, J., Melnikov, D., Manevich, A., and Romejko, V.: Noctilucent clouds: modern ground-based photographic observations by a digital camera network, Appl. Optics, 50, F72-F79, doi:10.1364/AO.50.000F72, 2011.

Fiedler, J., Baumgarten, G., and von Cossart, G.: Noctilucent clouds above ALOMAR between 1997 and 2001: Occurrence and properties, J. Geophys. Res., 108, 8453, doi:10.1029/2002JD002419, 2003.

Gardner, C. S., Papen, G. C., Chu, X., and Pan, W.: First lidar observations of middle atmosphere temperatures, Fe densities, and polar mesospheric clouds over the North and South poles, Geophys. Res. Lett., 28, 1199-1202, 2001.

Greenwald, R. A., Baker, K. B., Dudeney, J. R., Pinnock, M., Jones, T. B., Thomas, E. C., Villain, J.-P., Cerisier, J. -C., Senior, C., Hanuise, C., Hunsucker, R. D., Sofko, G., Koehler, J., Nielsen, E., Pellinen, R., Walker, A. D. M., Sato, N., and Yamagishi, H.: DARN/SuperDARN: A global view of the dynamics of highlatitude convection, Space Sci. Rev., 71, 761-796, 1995.

Hansen, G., Serwazi, M., and von Zahn, U.: First detection of a noctilucent cloud by lidar, Geophys. Res. Lett., 16, 1445-1448, 1989.

Hervig, M. and Siskind, D. E.: Decadal and inter-hemispheric variability in polar mesospheric clouds, water vapor, and temperature, J. Atmos. Sol. Terr. Phys., 68, 30-41, 2006.

Hoffmann, P., Singer, W., and Bremer, J.: Mean seasonal and diurnal variations of PMSE and winds from 4 years of radar observations at ALOMAR, Geophys. Res. Lett., 26, 1525-1528, 1999.

Höffner, J., Fricke-Begemann, C., and Lübken, F.-J.: First observations of noctilucent clouds by lidar at Svalbard, $78^{\circ} \mathrm{N}$, Atmos. Chem. Phys., 3, 1101-1111, doi:10.5194/acp-3-1101-2003, 2003.

Hosokawa, K., Ogawa, T., Yukimatu, A. S., Sato, N., and Iyemori, T.: Statistics of Antarctic mesospheric echoes observed with the SuperDARN Syowa Radar, Geophys. Res. Lett., 31, L02106, doi:10.1029/2003GL018776, 2004.

Hosokawa, K., Ogawa, T., Arnold, N. F., Lester, M., Sato, N., and Yukimatu, A. S.: Extraction of polar mesosphere summer echoes from SuperDARN data, Geophys. Res. Lett., 32, L12801, doi:10.1029/2005GL022788, 2005.

Huaman, M. M. and Kelley, M. C.: Mesosphere: Polar Summer Mesopause, in: Encyclopedia of Atmospheric Science, Elsevier Science, 2171-1279, 2002.

Kaifler, N., Baumgarten, G., Klekociuk, A. R., Alexander, S. P., Fiedler, J., and Lübken, F.-J.: Small scale structures of NLC 
observed by lidar at $69^{\circ} \mathrm{N} / 69^{\circ} \mathrm{S}$ and their possible relation to gravity waves, J. Atmos. Sol. Terr. Phys, in press, 2013.

Karlsson, B., Randall, C. E., Shepherd, T. G., Harvey, V. L., Lumpe, J., Nielsen, K., Bailey, S. M., Hervig, M., and Russell III, J. M.: On the seasonal onset of polar mesospheric clouds and the breakdown of the stratospheric polar vortex in the Southern Hemisphere, J. Geophys. Res., 116, D18107, doi:10.1029/2011JD015989, 2011.

Kirkwood, S., Wolf, I., Nilsson, H., Dalin, P., Mikhaylova, D., and Belova, E.: Polar mesosphere summer echoes at Wasa, Antarctica $\left(73^{\circ} \mathrm{S}\right)$ : First observations and comparison with $68^{\circ} \mathrm{N}$, Geophys. Res. Lett., 34, L15803, doi:10.1029/2007GL030516, 2007.

Kirkwood, S., Dalin, P., and Réchou, A.: Noctilucent clouds observed from the UK and Denmark - trends and variations over 43 years, Ann. Geophys., 26, 1243-1254, doi:10.5194/angeo-261243-2008, 2008.

Klekociuk, A. R., Morris, R. J., and Innis, J. L.: First Southern Hemisphere common-volume measurements of PMC and PMSE, Geophys. Res. Lett., 35, L24804, doi:10.1029/2008GL035988, 2008.

Lindzen, R. S.: Turbulence and stress owing to gravity wave and tidal breakdown., J. Geophys. Res., 86, 9707-9714, 1981.

Liu, J. Y., Pan, C. J., and Lee, C. C.: VHF radar and MF/HF dynasonde observations during polar mesosphere summer echoes conditions at EISCAT, Earth Planets Space, 54, 691-698, 2002.

Lübken, F.-J., Rapp, M., Blix, T., and Thrane, E.: Microphysical and turbulent measurements of the Schmidt number in the vicinity of polar mesosphere summer echoes, Geophys. Res. Lett., 25, 893896, 1998.

McClintock, W. E., Rusch, D. W., Thomas, G. E., Merkel, A. W., Lankton, M. R., Drake, V. A., Bailey, S. M., and Russell III, J. M.: The cloud imaging and particle size experiment on the Aeronomy of Ice in the Mesosphere mission: Instrument concept, design, calibration, and on-orbit performance, J. Atmos, 2009.

Morris, R. J., Murphy, D. J., Klekociuk, A. R., and Holdsworth, D. A.: First complete season of PMSE observations above Davis, Antarctica, and their relation to winds and temperatures, Geophys. Res. Lett., 34, L05805, doi:10.1029/2006GL028641, 2007.

Nicolls, M. J., Kelley, M. C., Varney, R. H., and Heinselman, C. J.: Spectral observations of polar mesospheric summer echoes at $33 \mathrm{~cm}(350 \mathrm{MHz})$ with PFISR, J. Atmos. Solar-Terr. Phys., 71, 662-674, 2009.

Ogawa, T., Nishitani, N., Sato, N., Yamagishi, H., and Yukimatu, A. S.: Upper mesosphere summer echoes detected with the Antarctic Syowa HF radar, Geophys. Res. Lett., 29, 61-1-61-4, doi:10.1029/2001GL014094, 2002.

Ogawa, T., Arnold, N. F., Kirkwood, S., Nishitani, N., and Lester, M.: Finland HF and Esrange MST radar observations of polar mesosphere summer echoes, Ann. Geophys., 21, 1047-1055, doi:10.5194/angeo-21-1047-2003, 2003a.

Ogawa, T., Hosokawa, K., Nishitani, N., Sato, N., Yamagishi, H., and Yukimatu, A. S.: Characteristics of polar mesosphere summer echoes observed with oblique incidence HF radars at Syowa Station, Adv. Polar Upper Atmos. Res., 17, 13-29, 2003 b.

Ogawa, T., Nozawa, S., Tsutsumi, M., Arnold, N. F., Nishitani, N., Sato, N., and Yukimatu, A. S.: Arctic and Antarctic polar mesosphere summer echoes observed with oblique incidence HF radars: analysis using simultaneous MF and VHF radar data, Ann. Geophys., 22, 4049-4059, doi:10.5194/angeo22-4049-2004, 2004.

Palmer, J. R., Rishbeth, H., Jones, G. O. L., and Williams, P. J. S.: A statistical study of polar mesosphere summer echoes observed by EISCAT, J. Atmos. Terr. Phys., 58, 307-315, 1996.

Ramos, C., Kelley, M. C., Djuth, F. T., Groves, K. M., Murayama, Y., Kawamura, S., and Thorsen, D.: Multifrequency observations of Polar Mesosphere Summer Echoes using Alaskan radar facilities: Comparisons and scattering calculations, Radio Sci., 44, RS5011, doi:10.1029/2008RS004102, 2009.

Rapp, M. and Lübken, F.-J.: Polar mesosphere summer echoes (PMSE): Review of observations and current understanding, Atmos. Chem. Phys., 4, 2601-2633, doi:10.5194/acp-4-2601-2004, 2004.

Reid, G. C.: Ice particles and electron "bite-outs" at the summer polar mesopause, J. Geophys. Res., 95, 13891-13896, 1990.

Romejko, V. A., Dalin, P. A., and Pertsev, N. N.: Forty years of noctilucent cloud observations near Moscow: database and simple statistics, J. Geophys. Res., 108, 8443, doi:10.1029/2002JD002364, 2003.

Röttger, J.: Polar mesosphere summer echoes: Dynamics and aeronomy of the mesosphere, Adv. Space Res., 14, 123-137, 1994.

Russell III, J. M., Bailey, S. M., Horańyi, M., Gordley, L. L., Rusch, D. W., Hervig, M. E., Thomas, G. E., Randall, C. E., Siskind, D. E., Stevens, M. H., Summers, M. E., Taylor, M. I., Englert, C. R., Espy, P. J., McClintock, W. E., and Merkel, A. W.: Aeronomy of Ice in the Mesosphere (AIM) Mission: Overview and early science results. J. Atmos. Sol.-Terr. Phys., 71, 316-330, doi:10.1016/j.jastp.2008.08.011, 2008.

Schwartz, M. J., Lambert, A., Manney, G. L., Read, W. G., Livesey, N. J., Froidevaux, L., Ao, C. O., Bernath, P. F., Boone, C. D., Cofield, R. E., Daffer, W. H., Drouin, B. J., Fetzer, E. J., Fuller, R. A., Jarnot, R. F., Jiang, J. H., Jiang, Y. B., Knosp, B. W., Krüger, K., Li, J.-L. F., Mlynczak, M. G., Pawson, S., Russell III, J. M., Santee, M. L., Snyder, W. V., Stek, P. C., Thurstans, R. P., Tompkins, A. M., Wagner, P. A., Walker, K. A., Waters, J. W., and Wu, D. L.: Validation of the Aura Microwave Limb Sounder temperature and geopotential height measurements, J. Geophys. Res., 113, D15S11, doi:10.1029/2007JD008783, 2008.

Smirnova, M., Belova, E., and Kirkwood, S.: Polar mesosphere summer echo strength in relation to solar variability and geomagnetic activity during 1997-2009, Ann. Geophys., 29, 563-572, doi:10.5194/angeo-29-563-2011, 2011.

Stevens M. H., Conway, R. R., Englert, C. R., Summers, M. E., Grossmann, K. U., and Gusev, O. A.: PMCs and the water frost point in the Arctic summer mesosphere, Geophys. Res. Lett., 28, 4449-4452, 2001.

Suzuki, H., Nakamura, T., Ejiri, M. K., Abo, M., Kawahara, T. D., Tomikawa, Y., and Tsutsumi, M.: A RAYLEIGH RAMAN LIDAR SYSTEM FOR TROPOSPHERE-MESOSPHERE OBSERVATIONS AT SYOWA STATION, ANTARCTICA, Reviewed and Revised Papers Presented at the 26th International Laser Radar Conference (ILRC 2012), S9P-18, 2012.

Takeda, Y.: Atmospheric phenomena at Syowa in 2009-10, Polar News, 91, 46, 9-13, 2010.

Taylor, M. J., Zhao, Y., Pautet, P., Nicolls, M. J., Collins, R. L., Barker-Tvedtnes, J., Burton, C. D., Thurairajah, B., Reimuller, J., Varney, R. H., Heinselman, C. J., and Mizutani, K.: Coordinated optical and radar image measurements of noctilucent clouds and 
polar mesospheric summer echoes, J. Atmos. Sol.-Terr. Phys., 71, 675-687, doi:10.1016/j.JASTP.2008.12.005, 2009.

Thayer, J. P., Rapp, M., Gerrard, A. J., Gudmundsson, E., and Kane, T. J.: Gravity wave influences on Arctic mesospheric clouds as determined by the Sondrestrom, Greenland, Rayleigh lidar, J. Geophys. Res., 108, 8449, doi:10.1029/2002JD002363, 2003.

Tsutsumi, M., Aso, T., and Ejiri, M.: Initial results of Syowa MF radar observations in Antarctica., Adv. Polar Upper Atmos. Res., 15, 103-116, 2001. von Zahn, U. and Bremer, J.: Simultaneous and common volume observations of noctilucent clouds and polar mesosphere summer echoes, Geophys. Res. Lett., 26, 1521-1524, doi:10.1029/1999GL900206, 1999.

Wickwar, V. B., Taylor, M. J., Herron, J. P., and Martineau, B. A.: Visual and lidar observations of noctilucent clouds above Logan, Utah, at $41.7^{\circ} \mathrm{N}$, J. Geophys. Res., 107, 4054, doi:10.1029/2001JD001180, 2002. 